\title{
TAWARRUQ BERASASKAN KREDIT PRABAYAR TELEFON: TINJAUAN TERHADAP PRODUK PEMBIAYAAN PERIBADI DI RHB ISLAMIC BANK
}

\author{
Siti Aishah Kasmon, ${ }^{\mathrm{a}} *$ Kamaruzaman Noordin ${ }^{\mathrm{b}}$ \\ a Jabatan Muamalat, Kolej Pengajian Islam Johor (MARSAH) \\ ${ }^{b}$ Jabatan Shariah dan Pengurusan, Akademi Pengajian Islam, Universiti Malaya, Kuala Lumpur \\ *Corresponding author: i_sha35@yahoo.com.my
}

Article history

Received: 2015-02-21

Received in revised form: 2015-07-13

Accepted: 2015-07-26

\begin{abstract}
Tawarruq was introduced in Malaysia as an alternative to controversial bay 'al-' $n a h$. However, the second type of tawarruq which is organized tawarruq was disputed by among scholars. The opponents claimed that the implementation of organized tawarruq is not complying Shariah requirements. The introduction of airtime credit as an underlying asset in tawarruq transaction by Sedania As Salam Capital Sdn Bhd (Sedania) is seems to neutralize the argumentation. Hence, this study aimed to review the implementation of tawarruq in personal financing product using airtime credit at Sedania's first client which is RHB Islamic Bank (RHBIB). Interview sessions with the representatives of Sedania and RHBIB will be held in collecting the information of the modus operandi and also using the literature review in studying the tawarruq concept. The study found that choosing Sedania as a platform in doing tawarruq transaction by using airtime credit as the commodity is the best solution in personal financing product. However, the consumption of this underlying asset in bigger market such as corporate banking and treasury should be considered and more research about this are suggested.
\end{abstract}

Keywords: Tawarruq, Airtime Credit, RHB Islamic Bank, Sedania as Salam Capital Sdn Bhd, Personal Financing, Underlying Asset 


\subsection{PENDAHULUAN}

Bay' al-' nah merupakan prinsip terawal yang diperkenalkan dalam pelbagai produk di Malaysia. (Saiful Azhar Rosly, 2005). Namun begitu, penggunaan prinsip ini telah menimbulkan pelbagai kontroversi di kalangan Sarjana Islam dan mereka menyarankan agar prinsip tawarruq digunakan sebagai alternatif bay' al-'nah di Malaysia (Ab. Ghani, Ab Mumin dan Che Abdullah, Ahmad Sufyan, 2006). Majoriti badan pengeluar fatwa di Timur Tengah dan Majlis Penasihat Syariah, Bank Negara Malaysia membenarkan penggunaan prinsip Tawarruq (Laldin, Mohamad Akram et al, 2012). Majma 'al-Fiqh alIslām ${ }^{-}$pula telah mengeluarkan resolusi yang bertentangan dengan keputusan mereka di mana dalam resolusinya yang bernombor 179 (19/5) menyatakan dengan jelas bahawa tawarruq individu dibenarkan dan mengharamkan tawarruq terancang kerana mengandungi elemen riba (I-FIKR, 2013).

Penentangan terhadap penggunaan tawarruq terancang adalah disebabkan oleh aplikasi semasa institusi kewangan dan perbankan Islam yang tidak mematuhi keperluan Syariah ('Alī Maḥmūd, Maḥmūd Muhammad, 2012). Aznan Hasan pernah mendedahkan tentang isu pemilikan aset yang berlaku dalam London Metal Exchange (LME) di mana suatu aset tertentu dijual kepada lebih daripada seorang pembeli. (Mohammed Khnifer, t.t). Hal ini bermaksud barang yang dijual oleh broker A kepada pelanggan B adalah barang yang sama dijual kepada pelanggan A. Oleh itu, pertindihan pemilikan aset telah berlaku dan hal ini jelas tidak memenuhi syarat sah jual beli di mana barang jualan mestilah dimiliki oleh penjual sebelum menjualnya kepada pembeli (Rayner, S.E, 1991).

Malaysia telah mengambil inisiatif menubuhkan Bursa Suq Al-Sila' (BSAS) pada tahun 2009 sebagai alternatif kepada LME (Syahnaz Sulaiman, t.t). Walaupun penubuhan BSAS telah menyelesaikan banyak isu Syariah yang timbul dalam LME, namun terdapat beberapa isu yang masih belum dapat diselesaikan sebagaimana yang pernah dibincangkan oleh Asyraf Wajdi Dusuki (Asyraf Wajdi Dusuki, 2010). Beliau membangkitkan kesangsian terhadap integriti urus niaga tawarruq dalam BSAS yang mengenakan pertambahan yuran pemprosesan sekiranya pembeli komoditi bercadang untuk mengambil komoditi yang dibelinya, kerana hal ini memberi gambaran bahawa penghantaran komoditi adalah tidak digalakkan dalam perjanjian tawarruq. Komoditi yang digunakan oleh BSAS adalah berbeza dengan LME di mana BSAS menggunakan minyak sawit mentah (CPO) dan plastik resin (Syahnaz Sulaiman, t.t), manakala LME menggunakan komoditi metal seperti aluminium, kuprum, paladium dan sebagainya (London Metal Exchange, 2014).

Sedania adalah satu lagi platform perdagangan komoditi tawarruq di Malaysia di mana keunikan platform ini berbanding platform-platform lain yang memperdagangkan komoditi tawarruq adalah penggunaan kredit prabayar telefon sebagai komoditi transaksi. Sedania mula memperkenalkan konsep kredit prabayar telefon sebagai komoditi tawarruq pada tahun 2009 dengan menggunakan sistem As-Sidq yang dibangunkannya sebagai platform yang akan mengautomatikkan jualan dan belian komoditi antara pelanggan, bank, pembekal dan pembeli komoditi. Perkhidmatan Sedania telah digunakan oleh beberapa institusi kewangan Islam untuk menjalankan transaksi tawarruq iaitu RHBIB, Malaysia Building Seciety Berhad, Bank Simpanan Nasional, Affin Islamic, Agro Bank, Koperasi Ukhwah, KOPUTRA dan Bank Rakyat (Amiruddin Amri, 2014).

Oleh itu, kajian ini akan membincangkan tentang modus operandi tawarruq yang menggunakan kredit prabayar telefon sebagai aset sandaran transaksi melalui platform Sedania. Penyelidik memilih RHBIB sebagai kajian kes dengan memfokuskan kepada modus operandi dalam produk pembiayaan peribadi kerana bank ini merupakan pelanggan pertama Sedania ketika konsep penggunaan kredit prabayar telefon sebagai komoditi tawarruq mula-mula diperkenalkan (Amiruddin Amri, 2014). Penyelidik memulakan perbincangan ini dengan pengenalan dan disusuli dengan konsep tawarruq yang meliputi definisi, gambaran dan pandangan fuqaha terhadap tawarruq. Perbincangan diteruskan dengan modus operandi produk pembiayaan peribadi berasaskan tawarruq di RHBIB. Disamping itu, penyelidik membincangkan secara ringkas berkenaan dengan kelebihan dan kelemahan menggunakan kredit prabayar telefon sebagai komoditi tawarruq sebelum penyelidik mengakhiri perbincangan dengan merumuskan keseluruhan perbincangan yang telah dibuat di bahagian penutup. 


\subsection{KONSEP TAWARRUQ}

\subsection{Definisi Tawarruq}

Menurut Muhammad Taqī al-'Uthmānī, perkataan tawarruq tidak terdapat dalam istilah bahasa. Ia di ambil daripada perkataan al-wariq jamaknya awrāq yang bermaksud al-fiḍ̂h iaitu peraksama ada berlipat ganda ataupun tidak (Munazzamah al-'Arabiyah li'l-Tarbiyah, 1988). Tawarruq adalah istilah yang digunakan oleh para fuqaha terhadap seseorang yang memikul tanggungjawab bagi memperoleh wang (Al-'uthmān̄̄, Muhammad Taqī, t.t). Oleh itu, perkataan tawarruq bermaksud talaba al-wariq iaitu meminta wang. Al-wariq yang dimaksudkan pada asalnya ialah wang yang diperbuat daripada al-fiddah iaitu perak. Kemudian, ia berubah menjadi umum sama ada wang yang diperbuat daripada perak, emas atau wang kertas (Al-Manī', 'Abd Allah Sulaymān, 1425H).

Istilah tawarruq tidak digunakan oleh para fuqaha empat mazhab kecuali mazhab Hanbali. Namun begitu, mereka ada membincangkan tentang bentuk jual beli tawarruq dalam perbincangan bay' al- ' $n a h$. Merujuk kepada kitab Al-Mawsū'ah Al-Fiqhiyyah, tawarruq ialah membeli sesuatu barang secara tangguh, kemudian menjualnya secara tunai kepada bukan penjual asal (pihak ketiga) dengan harga yang lebih rendah daripada harga yang dibelinya bagi memperoleh wang tunai (Wizārah al-Awqāf wa alSyu'ūn al-Islāmiyyah t.t, 14:147). Definisi ini adalah sama seperti definisi tawarruq yang diberikan oleh Wahbah al-Zuhaylī (2004, 5:3475) dan Nazīh Hamād (1993). Definisi ini juga hampir sama dengan definisi tawarruq oleh Majma ' al-Fiqh ${ }^{-}$al-Islām ${ }^{-}$yang merujuk tawarruq sebagai membeli komoditi yang berada dalam pemilikan penjual dengan harga tangguh. Kemudian pembeli tersebut menjualnya secara tunai bukan kepada penjual asal iaitu kepada pihak ketiga bagi mendapatkan wang tunai.

Selain itu, Muhammad Rawwas Qal'ah Jī memberi takrif tawarruq sebagai perumpamaan mengenai pinjaman kepada jualan benda yang nyata kepada peminjam dengan harga yang lebih tinggi secara tangguh untuk dijual bagi mendapatkan apa yang dihajati berupa wang tunai (Qal'ah $\mathrm{j}$, Muhammad Rawwas, 1996). Walaupun terdapat pelbagai gaya bahasa yang berlainan yang diberikan oleh para sarjana dalam memberikan definisi tawarruq seperti yang dibincangkan di atas, kajian ini menyimpulkan bahawa mereka sepakat dalam tiga perkara utama berkenaan dengan definisi tawarruq iaitu:

1) Membeli sesuatu barang secara tangguh.

2) Kemudian menjual semula barang tersebut kepada pihak ketiga secara tunai.

3) Tujuan transaksi tawarruq adalah bagi memperoleh wang tunai.

\subsection{Gambaran Tawarruq}

Para sarjana kontemporari telah membahagikan tawarruq kepada tiga jenis iaitu al-tawarruq al-fardi (real tawarruq), al-tawarruq al-munazzam (organized tawarruq) dan al-tawarruq al-mașrifi (banking tawarruq). Walau bagaimanapun, Sāmī Ibrāhīm al-Suwaylim dan beberapa sarjana lain menganggap bahawa banking tawarruq adalah sebahagian daripada bentuk organized tawarruq kerana struktur keduadua jenis tersebut adalah sama, cuma yang membezakannya adalah entiti yang menguruskan prosedur tawarruq, di mana banking tawarruq dijalankan oleh pihak perbankan (Bouheraoua, Sa'id, t.t). Oleh itu, kajian ini menyimpulkan bahawa gambaran tawarruq boleh dikategorikan kepada dua jenis, iaitu:

\subsubsection{Tawarruq Individu}

Tawarruq Individu adalah transaksi yang berlaku dalam keadaan pembeli pertama membeli barangan secara ansuran dan menjualnya kepada pihak ketiga secara tunai dengan harga yang rendah. Tawarruq ini dikenali sebagai tawarruq al-fardi/al-fiqh- (Ab Mumin Ab. Ghani dan Ahmad Sufyan Che Abdullah, 2006). Muhammad Rawwās Qal'ah Jī menggambarkan tawarruq ini sebagai seseorang yang memerlukan wang menghampiri peniaga dan membeli barangan dengan bayaran secara ansuran bagi tempoh yang diketahui. Setelah mengambil barangan yang dibelinya, pembeli tersebut menjualnya di pasaran secara tunai dengan harga yang lebih rendah daripada harga yang dibelinya. Ketika membeli barangan, pembeli tersebut tidak mempunyai niat untuk menggunakannya tetapi dia menjual semula barangan tersebut 
walaupun dengan harga yang lebih rendah, adalah semata-mata bagi mendapatkan wang tunai. Oleh kerana pembeli tersebut dilarang menjual semula barangan tersebut kepada penjual asal bagi mengelakkan transaksi bay' al-' nah, maka dia menjualnya kepada pihak ketiga. (Qal'ah $\mathfrak{\jmath}$, Muhammad Rawwās, 2002).

\subsubsection{Tawarruq Terancang}

Tawarruq terancang dikenali sebagai tawarruq al-mașrifi (banking tawarruq) atau tawarruq almunazzam (organized tawarruq). Tawarruq terancang digunakan dalam sesebuah sistem kewangan di mana tawarruq menjadi satu kaedah pembiayaan atau pinjaman. Di dalam tawarruq terancang, mungkin terjadi pembeli barangan terakhir bertindak sebagai wakil kepada penjual barangan pertama ataupun penjual pertama akan mewakili pembeli terakhir dalam menguruskan kontrak (Ab Mumin Ab. Ghani dan Ahmad Sufyan Che Abdullah, 2006). Hal ini selari dengan gambaran tawarruq terancang oleh Muḥammad Uthmān Shubayr di mana seorang pelanggan pergi kepada bank Islam dan berkata 'Saya inginkan wang tunai melalui kaedah tawarruq'. Kemudian pihak bank membeli untuknya komoditi di pasaran antarabangsa dan menjualnya kepada pelanggan tersebut secara tangguh dan ansuran. Seterusnya, pihak bank meminta untuk menjadi wakil pelanggan bagi menjual komoditi tersebut. Kemudian, pelanggan tersebut akan memperoleh wang tunai (harga komoditi tersebut) dalam akaunnya dan pelanggan terikat untuk membayar harga komoditi tersebut secara ansuran (Shubayr, Muhammad 'Uthmān, t.t).

Majma ' al-Fiqh' ${ }^{-}$al-Islām ${ }^{-}$menggambarkan tawarruq yang digunakan dalam operasi perbankan pada hari ini (yang dikenali sebagai organized tawarruq) di mana pihak bank menjual komoditi yang dibeli daripada pasaran komoditi antarabangsa kepada pelanggan secara kredit. Kemudian berdasarkan perjanjian yang dilakukan dalam kontrak, pihak bank akan menjadi wakil kepada pelanggan tersebut bagi menjual komoditi yang sama kepada pihak lain secara tunai dan sejumlah wang akan diserahkan kepada pelanggan (Muslim World League Islamic Fiqh Council, 2003).

\subsection{Pandangan Fuqaha Terhadap Tawarruq}

\subsubsection{Pandangan Fuqaha Silam}

Para fuqaha silam berbeza pandangan terhadap hukum tawarruq. Perbezaan pandangan ini telah melahirkan tiga hukum yang berlainan iaitu harus, haram dan makruh (Al-'Uthaymīn, Muhammad Șāliḥ, 2005) seperti berikut:

\section{a) Harus}

Majoriti fuqaha empat mazhab mengharuskan tawarruq (Wizārah al-Awqāf wa al-Syu'ūn alIslāmiyyah, t.t: 14:147). Namun begitu, pandangan ini telah ditentang oleh Rafīq Yūnus al-Miṣrī dengan menyatakan bahawa hanya sebahagian fuqaha mazhab Hanbali sahaja yang mengharuskannya (Al-Mișrī, Rafiq Yūnus, 2001). Majoriti fuqaha mazhab Hambali yang mengharuskan tawarruq ialah al-Mardāwī, Ibn Mufliḥ, dan al-Buhūtī (Al-'uthmān̄̄, Muhammad Taqī, t.t). Manakala, fuqaha mazhab Hanafi yang mengharuskan tawarruq ialah Imām Abū Yūsuf (Shubayr, Muhammad 'Uthmān, t.t). Menurut Imam Syafie dalam kitab al-Umm, jika seorang lelaki membeli barangan secara tangguh, tidak mengapa jika dia menjual semula barangan tersebut kepada penjual asal atau pihak lain dengan harga yang lebih rendah atau lebih tinggi daripada harga yang dibelinya (Al-Shāfi $\left.{ }^{\prime} \bar{\imath}, 1968\right)$. Ibn Juzayy pula menyatakan bahawa harus jika menjual barangan tersebut kepada pihak ketiga (Ibn Juzayy, t.t).

\section{b) Haram}

Sebahagian daripada fuqaha mazhab Hambali dan Hanafi mengharamkan tawarruq (Shubayr, Muhammad 'Uthmān, t.t). Fuqaha mazhab Hambali yang mengharamkannya adalah Ibn Taymiyah dan 
anak muridnya Ibn Qayyim (Al-Rashīdī, Ahmad Fahd, 2005). Sebahagian ulama mutakhir hanafiyah yang mengharamkan tawarruq ialah al-Ḥașkafī dan Imam Muḥammad (Al-Uthmānī, Muḥammad Taqī, t.t).

c) Makruh

Sebahagian fuqaha mazhab Hambali berpendapat bahawa tawarruq adalah makruh iaitu 'Umar 'Abd al-'Azīz. Selain itu, salah satu riwayat Hanafi iaitu Muhammad al-Ḥasan al-Shaybānī juga berpandangan bahawa tawarruq adalah makruh (Al-Rashīdī, Aḥmad Fahd, 2005).

\subsubsection{Pandangan Sarjana Kontemporari}

a) Harus

Sebahagian besar fuqaha kontemporari mengharuskan tawarruq. Contohnya Shaykh 'Abd al-'Azīz Bāz, Shaykh Muḥammad Ibrāhīm, Shaykh 'Abd Allah Sulaymān al-Manī', Shaykh 'Abd al-Raḥman alSa 'udī dan Shaykh Yūsuf al-Qaraḍāwī (Al-Rashīdī, Aḥmad Fahd, 2005). Tawarruq juga diharuskan oleh Bank Negara Malaysia (BNM), Accounting and Auditing Organisation for Islamic Financial Insttutions (AAOIFI), Dallah al-Barakah Bank (DAB), Kuwait Finance House (KFH) dan Dubai Islamic Bank (DIB) (Laldin, Mohamad Akram et al, 2012).

b) Haram

Sebahagian fuqaha semasa yang mengharamkan tawarruq adalah Rafīq Yūnus al-Mișrī, Sāmī alSuwaylim, Șālih al-Hușīn, Husīn Hāmid, dan 'Abd al-Jabbar al-Subhān̄̄ (Al-Rashīdī, Aḥmad Fahd, 2005). Majma ' al-Fiqh' ${ }^{-}$al-Isläm ${ }^{-}$pula telah mengeluarkan tiga peringkat keputusan berkaitan tawarruq. Pada peringkat pertama yang diadakan pada bulan Oktober 1998 (Rejab 1419H) dalam sesi ke-15, mereka mengharuskan kontrak tawarruq dengan syarat pembeli tidak menjual barang kepada penjual asal untuk mengelakkan unsur bay' al- 'nah (Majma' al-Fiqhī al-Islāmī, 1419H). Pada bulan Disember 2003 dalam sesi ke-17, Majma' al-Fiqhī al-Islām̄̄ telah membezakan antara al-tawarruq al-fardi (Real Tawarruq) dengan al-tawarruq al-mașrifi (Organized Tawarruq) di mana tawarruq al-fardi adalah dibenarkan sedangkan tawarruq yang kedua yang digunakan secara meluas oleh perbankan Islam pada hari ini tidak dibenarkan kerana ia seakan-akan menyerupai bay' al-'nah (Muslim World League Islamic Fiqh Council, 2003). Akhirnya, Pada bulan April 2009 dalam sesi ke-19 yang diadakan di Sharjah, United Arab Emirates, Majma ' al-Fiqh ${ }^{-}$al-Islām ${ }^{-}$secara rasmi mengharamkan penggunaan tawarruq al-mașrifi (I-FIKR, 2013).

\subsection{PRODUK PEMBIAYAAN PERIBADI BERASASKAN TAWARRUQ DI RHBIB}

RHBIB menggabungkan konsep komoditi murabahah dengan tawarruq dalam produk-produk tawarruq mereka. ${ }^{1}$ RHBIB merujuk komoditi murabahah sebagai menjual suatu komoditi yang berfungsi sebagai aset sandaran bagi sesuatu transaksi. Kemudian, pelanggan akan membuat pembayaran bagi harga jualan komoditi tersebut secara ansuran menggunakan konsep murabahah iaitu harga asal ditambah dengan keuntungan. Seterusnya, konsep tawarruq digunakan apabila pelanggan menerima wang tunai sebagai pertukaran dengan komoditi tersebut yang dijual kepada pihak ketiga (RHB Islamic Bank, 2014).

Produk-produk RHBIB yang menggunakan konsep tawarruq boleh dibahagikan kepada dua jenis, iaitu produk pembiayaan dan deposit. Produk-produk pembiayaan yang menggunakan tawarruq di RHBIB kebanyakannya adalah produk pembiayaan peribadi dan ada sedikit produk-produk untuk

${ }^{1}$ RHB Islamic Bank Berhad menggunakan konsep murabahah dan tawarruq dalam produk deposit manakala konsep Komoditi Murabahah melalui tawarruq digunakan dalam produk pembiayaan. 
korporat dan komersil (Mohammad Nasir Kamis, 2014) seperti Pembiayaan Bertempoh-i Komoditi Murabahah, Kredit Pusingan-i Komoditi Murabahah, dan Overdraf-i Komoditi Murabahah (RHB Islamic Bank, 2014). Produk deposit yang menggunakan konsep tawarruq di RHBIB pula adalah Deposit-i Komoditi Murabahah (CMD-i) (Mohammad Nasir Kamis, 2014).

Produk pembiayaan peribadi di RHBIB adalah pembiayaan jangka pendek yang tidak bercagar yang menyediakan wang tunai kepada pelanggan (RHB Islamic Bank, 2014). Menurut Mohammad Nasir Kamis@ Che Ali, perkhidmatan pembiayaan peribadi ialah bank memberi tunai kepada pelanggan dengan cara membuat perdagangan. (Mohammad Nasir Kamis, 2014). Ia dinamakan sebagai pembiayaan peribadi kerana pelanggan menggunakan kemudahan ini untuk menampung penggunaan peribadinya seperti ubah suai rumah, menyelesaikan pinjaman dan sebagainya selagi penggunaan tersebut tidak bertentangan dengan prinsip-prinsip Syariah (RHB Islamic Bank, 2014). RHBIB mula mengaplikasikan konsep tawarruq sejak mula-mula bank ini memperkenalkan produk pembiayaan peribadi iaitu pada tahun 2008. Sebelum itu, RHBIB hanya menawarkan pinjaman peribadi konvensional (Mohammad Nasir Kamis, 2014).

Penggunaan dana RHBIB terhadap aktiviti pembiayaan peribadi adalah sangat sedikit berbanding dengan produk-produk pembiayaan bertempoh lain iaitu sekitar 2.9 peratus sahaja secara purata bagi setahun seperti yang ditunjukkan dalam Jadual 1.

Jadual 1: Pengelasan Pembiayaan di RHB Islamic Bank Berhad Mengikut Jenis Tahun 2009-2014.

\begin{tabular}{lcccccc}
\hline \multicolumn{1}{c}{$\begin{array}{c}\text { Jenis } \\
\text { Pembiayaan }\end{array}$} & $\begin{array}{c}\mathbf{2 0 0 9} \\
\mathbf{( \% )}\end{array}$ & $\begin{array}{c}\mathbf{2 0 1 0} \\
\mathbf{( \% )}\end{array}$ & $\begin{array}{c}\mathbf{2 0 1 1} \\
\mathbf{( \% )}\end{array}$ & $\begin{array}{c}\mathbf{2 0 1 2} \\
\mathbf{( \% )}\end{array}$ & $\begin{array}{c}\mathbf{2 0 1 3} \\
\mathbf{( \% )}\end{array}$ & $\begin{array}{c}\mathbf{2 0 1 4} \\
\mathbf{( \% )}\end{array}$ \\
\hline $\begin{array}{l}\text { Kemudahan Tunai } \\
\text { Pembiayaan }\end{array}$ & 1.44 & 1.29 & 0.9 & 0.93 & 0.93 & 0.94 \\
$\begin{array}{l}\text { Bertempoh: } \\
\begin{array}{l}\text { Pembiayaan } \\
\text { Perumahan }\end{array}\end{array}$ & & & & & & \\
$\begin{array}{l}\text { Pembiayaan } \\
\text { Bersindiket }\end{array}$ & 30.76 & 26.21 & 21.1 & 21.34 & 24.33 & 24.84 \\
$\begin{array}{l}\text { Sewa Beli Belum } \\
\text { Terima }\end{array}$ & 13.03 & 9.95 & 2.6 & 2.36 & 2.35 & 1.19 \\
$\begin{array}{l}\text { Pembiayaan } \\
\text { Bertempoh Lain }\end{array}$ & 17.02 & 17.99 & 27.2 & 27.15 & 26.29 & 25.17 \\
$\begin{array}{l}\text { Pembiayaan Peribadi } \\
\text { Bil Belum Terima / }\end{array}$ & 21.31 & 32.12 & 40.9 & 35.86 & 33.41 & 39.24 \\
$\begin{array}{l}\text { Penerimaan Kredit } \\
\text { Resit Amanah }\end{array}$ & $0.23 *$ & $0.16^{*}$ & $1.8 *$ & $3.98 *$ & $5.8 *$ & $5.5 *$ \\
$\begin{array}{l}\text { Pembiayaan } \\
\text { Kakitangan }\end{array}$ & 8.27 & 6.05 & 4.0 & 5.24 & 3.57 & 2.65 \\
$\begin{array}{l}\text { Kredit / Caj Kad } \\
\text { Belum Terima } \\
\text { Pembiayaan Pusingan }\end{array}$ & 0.54 & 0.20 & 0.2 & 0.13 & 0.19 & 1.10 \\
\hline
\end{tabular}

Sumber: Penyata Kewangan RHB Islamic Bank Berhad 2009-2014 dan Mohammad Nasir Kamis.

* Peratusan pembiayaan peribadi termasuk dalam pembiayaan bertempoh lain.

Jadual tersebut menunjukkan bahawa hampir 50 peratus dana bank disalurkan kepada aktiviti pembiayaan perumahan dan sewa beli. Purata pengeluaran dana kepada pembiayaan perumahan adalah sebanyak 24.76 peratus setahun dan 23.47 peratus setahun purata bagi aktiviti pembiayaan sewa beli. Sebahagian lagi dana RHBIB pula digunakan untuk aktiviti-aktiviti pembiayaan yang lain termasuklah aktiviti pembiayaan peribadi. Perbezaan trend penggunaan dana pembiayaan peribadi dengan pembiayaan perumahan dan sewa beli bagi RHBIB boleh ditunjukkan dalam rajah 1. 
Rajah 1: Perbezaan Trend Penggunaan Dana RHB Islamic Bank Berhad Antara Jenis Pembiayaan Perumahan, Sewa Beli, dan Pembiayaan Peribadi Tahun 2009-2014.

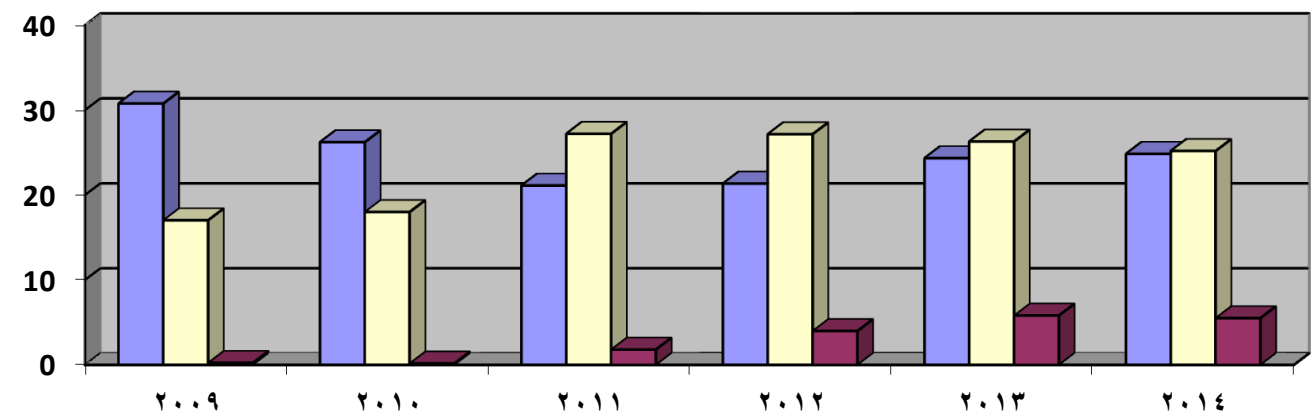

口Pembiayaan Perumahan 口Pembiayaan Sewa Beli aPembiayaan Peribadi

Rajah 1 menunjukkan bahawa produk pembiayaan peribadi merupakan jenis pembiayaan yang minimum yang diperuntukkan oleh RHBIB dalam penggunaan dana bank tersebut. Namun begitu, penggunaan dana terhadap pembiayaan ini mengalami peningkatan yang mendadak pada tahun 2011 dan meningkat sehingga tahun 2013 dan turun 0.3 peratus pada tahun 2014. Kajian ini menjangkakan bahawa pembiayaan ini akan mengalami peningkatan yang berterusan pada masa akan datang. Walaupun pembiayaan perumahan merupakan jenis pembiayaan yang paling utama yang diperuntukkan dalam penggunaan dana RHBIB, namun ia mengalami penurunan setiap tahun sehingga tahun 2012 dan meningkat pada tahun 2013 dan 2014. Pembiayaan sewa beli pula mengalami peningkatan setiap tahun sehingga tahun 2012 dan menurun pada tahun 2013 dan 2014.

\subsection{Modus Operandi Produk Pembiayaan Peribadi Tawarruq di RHBIB}

Rajah 2: Modus Operandi Perdagangan Komoditi Produk Pembiayaan Peribadi di RHBIB

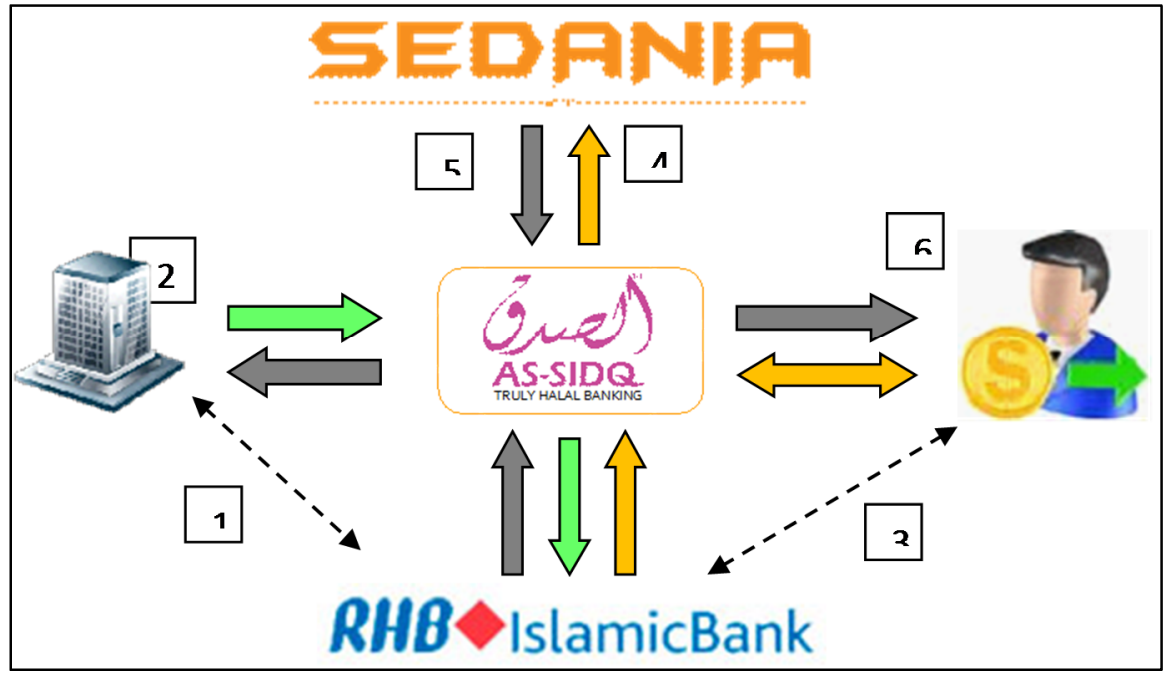

Menunjukkan aliran wang tunai.

Menunjukkan aliran airtime daripada pembekal kepada bank.

Menunjukkan aliran airtime daripada bank kepada pelanggan dan kepada Sedania

Sumber: Mohammad Nasir Kamis, 2014. 
Berdasarkan rajah 2, andaikan pelanggan datang ke RHBIB untuk memohon pembiayaan peribadi sebanyak RM10, 000. Maka, pelanggan akan memberi dokumen-dokumen yang diperlukan seperti penyata gaji kepada pihak bank. Pada waktu ini juga, pelanggan akan diberikan dokumen-dokumen sepert Surat Tawaran, Pesanan Belian Komoditi, Surat Penerimaan Jualan Murabahah, dan Tawaran Penjual untuk ditandatangani bagi mendapatkan persetujuan daripada pelanggan berkenaan terma dan syarat pembiayaan bagi membolehkan pihak bank melaksanakan transaksi perdagangan komoditi. Kemudian pihak bank akan menyemak kelayakan pelanggan seperti CTOS, CCRIS dan sebagainya. Apabila pelanggan tersebut layak memohon pembiayaan peribadi sebanyak RM10, 000, maka pihak bank mula melaksanakan perdagangan komoditi (Mohammad Nasir Kamis, 2014). Enam langkah yang perlu dilalui oleh pihak-pihak yang terlibat dalam pembelian dan penjualan komoditi bagi produk pembiayaan peribadi adalah seperti berikut:-

\section{Pertama:}

RHBIB membeli komoditi yang berharga RM 10, 000 daripada pembekal melalui sistem As-Sidq. Pembekal tersebut terdiri daripada syarikat-syarikat telco seperti Maxis, Celcom dan sebagainya. Komoditi yang digunakan dalam transaksi ini adalah prabayar telefon (airtime).

$\underline{\text { Kedua: }}$

Maka, pembekal menjual airtime yang berharga RM10, 000 kepada RHBIB melalui sistem As-Sidq. Komoditi tersebut kini sudah menjadi milik pihak bank.

Ketiga:

RHBIB menjual airtime yang berharga RM10, 000 ditambah dengan X\% keuntungan kepada pelanggan melalui sistem $A s-S i d q$ dengan menggunakan konsep murabahah. Pada waktu ini, sistem $A s-S i d q$ akan menghantar Short Message Service (SMS) kepada pelanggan menyatakan bahawa pihak bank bersetuju untuk menawarkan pembiayaan peribadi kepada pelanggan berjumlah RM10, 000. SMS tersebut juga mengandungi maklumat-maklumat terperinci berkenaan dengan pembiayaan seperti kadar keuntungan, jumlah bayaran bulanan, maklumat komoditi dan sebagainya. Pelanggan juga diberi pilihan sama ada mahu meneruskan permohonan pembiayaan peribadi ini ataupun mahu membatalkannya. Sekiranya pelanggan bersetuju untuk meneruskan permohonan, pelanggan perlu membalas YA bagi menjual komoditi kepada Sedania dan menerima wang tunai. Balasan TIDAK menunjukkan pelanggan mahu memiliki komoditi dan balasan CANCEL pula sekiranya pelanggan mahu membatalkan permohonan pembiayaan.

\section{Keempat:}

Sedania membeli airtime sebanyak RM10, 000 daripada pelanggan melalui As-Sidq. Sebenarnya, pelanggan sudah melantik pihak bank sebagai wakil untuk menjualkan airtime tersebut kepada Sedania rentetan daripada jawapan YA oleh pelanggan terhadap SMS yang diberi serta semasa pelanggan menandatangani dokumen Surat Tawaran sebelum ini.

\section{Kelima:}

Sedania membayar (tunai) kepada pelanggan melalui $A s$-Sidq. Apabila wang tunai tersebut sudah menjadi hak milik pelanggan, pihak bank akan mengambil wang tersebut dari akaun Al-Sidq dan masukkan pula ke dalam akaun pelanggan.

\section{Keenam:}

Pelanggan menerima wang tunai melalui As-Sidq. Pelanggan berjaya mendapatkan wang tunai seperti yang dikehendaki setelah pihak bank memasukkan wang tersebut ke dalam akaun bank pelanggan. Kemudian, pihak bank akan menyerahkan semula dokumen-dokumen yang telah ditandatangani oleh pelanggan sebelum ini seminggu selepas pelanggan menerima wang tunai. Kini, pelanggan terikat untuk membayar hutangnya secara ansuran kepada pihak bank. 


\subsection{KELEBIHAN DAN KELEMAHAN MENGGUNAKAN KREDIT PRABAYAR TELEFON SEBAGAI KOMODITI TAWARRUQ MELALUI SEDANIA}

\subsection{Kelebihan}

a) Sistem $A l-S i d q$ yang mesra pengguna

Sistem $A l-S i d q$ adalah sistem yang mesra pengguna kerana sistem ini menguruskan transaksi secara automatik. RHBIB diberi hak untuk mengakses sistem Al-Sidq bagi menjalankan perdagangan. Oleh kerana sistem ini berasaskan laman web, maka ia boleh diakses di mana-mana dan pada bila-bila masa. Sistem ini juga menyediakan perkhidmatan penghantaran SMS kepada pelanggan supaya pelanggan tersebut dapat membuat pilihan sama ada mahu meneruskan permohonan pembiayaan peribadi ataupun tidak. Seterusnya, sistem ini berupaya merekodkan semua transaksi perdagangan komoditi dan boleh dirujuk oleh pihak bank (Amiruddin Amri, 2014). Segala kemudahan yang disediakan oleh Sedania ini sangat memudahkan urusan pihak bank dan proses penjualan dan pembelian komoditi dapat diselesaikan dengan cepat.

b) Kredit prabayar telefon mempunyai ciri-ciri komoditi yang unik, iaitu:

- Penggunaan kredit prabayar telefon di Malaysia sentiasa mendapat permintaan yang tinggi daripada pengguna. Jumlah penggunaannya boleh mencecah sehingga seratus juta setiap hari (Amiruddin Amri, 2014). Oleh itu, penggunaan komoditi ini dapat memenuhi keperluan institusi perbankan Islam dalam menyediakan kemudahan tawarruq.

- Nilai kredit prabayar bersifat tetap di mana ia tidak akan dipengaruhi oleh turun naik harga. Contohnya, jika kredit prabayar telefon dibeli pada hari ini dengan harga RM10, harga tersebut tetap sama pada 2 atau 3 tahun akan datang (Amiruddin Amri, 2014).

- Komoditi prabayar telefon tidak memerlukan gudang penyimpanan seperti komoditi-komoditi lain. Ia hanya bergantung kepada enjin syarikat telco. Oleh itu, ia tidak memerlukan yuran penghantaran, yuran penyelenggaraan dan yuran penyimpanan (Amiruddin Amri, 2014). Hal ini dapat mengurangkan kos pengurusan.

c) Penghantaran komoditi boleh dilaksanakan secara terus ke pasaran

Sekiranya pelanggan berhasrat untuk memiliki komoditi yang dibeli, pihak Sedania berupaya menghantar kredit prabayar secara terus kepada pelanggan. Nombor-nombor siri kredit prabayar ada disenaraikan di dalam $C D$ dan boleh diberikan kepada pelanggan dengan mudah (Amiruddin Amri, 2014). Pihak RHBIB pula hanya akan meminta pelanggan supaya menanggung kos penghantaran. (Mohammad Nasir Kamis, 2014). Kemudahan pelanggan untuk memiliki komoditi ini menunjukkan ketelusan dan integriti jual beli tawarruq.

\subsection{Kelemahan}

a) Yuran perdagangan yang agak mahal

Sedania mengenakan yuran perdagangan kepada RHBIB adalah sebanyak RM60 untuk satu transaksi. RHBIB mengambil inisiatif untuk berkongsi tanggungan yuran tersebut dengan pelanggan atas arahan Bank Negara Malaysia. Maka, RHBIB menanggung 50 peratus daripada RM60 tersebut dan 50 peratus lagi ditanggung oleh pelanggan. Walaupun yuran yang dikenakan oleh Sedania agak mahal, namun jumlah tersebut berbaloi dengan semua perkhidmatan yang disediakan oleh Sedania (Mohammad Nasir Kamis, 2014). 
b) Terhad kepada perniagaan runcit

Penggunaan kredit prabayar telefon sebagai komoditi tawarruq hanya terhad kepada perniagaan runcit seperti pembiayaan peribadi, kad kredit dan deposit (Amiruddin Amri, 2014). Hal ini kerana perniagaan runcit hanya melibatkan amaun yang kecil berbanding perbankan korporat dan perbendaharaan yang melibatkan jumlah yang besar. Walaupun pihak Sedania tiada masalah untuk mewujudkan komoditi tersebut dalam jumlah yang besar (Ibid, 2014), namun kajian yang lebih terperinci perlu dilakukan terhadap perbandingan permintaan pasaran terhadap kredit prabayar dengan keperluan industri perbankan Islam terhadap komoditi tersebut sebelum kredit prabayar digunakan untuk perbankan korporat dan perbendaharaan agar tidak berlaku lebihan komoditi ataupun kekurangan permintaan pasaran.

\subsection{KESIMPULAN}

Tawarruq ialah pembelian sesuatu barang secara tangguh dan kemudian menjualnya kepada pihak ketiga secara tunai dengan harga yang lebih rendah daripada harga yang dibelinya secara tangguh bagi memperolehi wang tunai. RHBIB menggunakan konsep komoditi murabahah melalui tawarruq dalam produk pembiayaan peribadinya. Produk ini hanya digunakan sebanyak 2.9 peratus sahaja secara purata setahun dalam penggunaan dana RHBIB. RHBIB telah memilih Sedania sebagai platform perdagangan komoditi tawarruq melalui sistem Al-Sidq. Sedania menyediakan kredit prabayar telefon sebagai komoditi atau aset sandaran transaksi tawarruq. Kredit prabayar telefon yang mempunyai ciri-ciri yang unik dan ditambah pula dengan sistem $\mathrm{Al}$-Sidq yang mesra pengguna menunjukkan bahawa penggunaan komoditi ini oleh RHBIB adalah sangat berkesan. Disamping itu, penjual asal komoditi yang merupakan pembekal kredit prabayar telefon dan pembeli komoditi iaitu Sedania merupakan dua pihak yang berlainan menunjukkan bahawa peristiwa komoditi kembali kepada penjual asal tidak akan berlaku. Sedania bukanlah pembeli akhir komoditi tawarruq. Setelah membeli komoditi daripada pelanggan, Sedania akan menyerahkan komoditi kepada Clearing House yang akan menjual komoditi-komoditi tersebut kepada pasaran (Amiruddin Amri, 2014). Walaupun yuran perdagangan yang dikenakan agak tinggi, namun ketiadaan yuran penambahan kepada pelanggan yang ingin memiliki komoditi menunjukkan ketelusan transaksi tawarruq. Akhir sekali, oleh kerana penggunaan komoditi ini hanya terhad kepada aktiviti perniagaan runcit sahaja, maka kajian yang lebih terperinci wajar dilakukan bagi memenuhi keperluan komoditi prabayar telefon dalam pasaran perbankan Islam.

\section{Rujukan}

Ab Mumin Ab. Ghani dan Ahmad Sufyan Che Abdullah. (2006). Tawarruq: Konsep dan Aplikasi dalam Kewangan Islam. Dalam Ab. Ghani, A.M. dan Mansor, F, Dinamisme Kewangan Islam di Malaysia. Kuala Lumpur: Penerbit Universiti Malaya.

Al-Manī','Abd Allah Sulaymān. (1425H). Al-Ta’șl al-Fiqh' lil Tawarruq f Daw' al-Ihtiyājāt alTamw'lyah al-Mu'āșirah. Majalah al-Buhūth al-Islāmiyah.

Al-Mișrī, Rafīq Yūnus. (2001). Al-Jāmi' $f^{2} U s ̦ u ̄ l ~ a l-R i b \bar{a}$. Dimashq: Dār al-Qalam, 175.

Al-Rashīdī, Aḥmad Fahd. (2005). 'Amaliyāt al-Tawarruq wa Tațb-qūtuhā al-Iqtișādiyah f'al-Mașārif alIslāmiyah. Amman: Dār al-Nafā'is.

Al-Shāfi'ì. (1968). Al-Umm. T.tp: Dār al-Sha‘b. 3:79.

Al-'Uthaymīn, Muḥammad Șāliḥ. (2005). Fatāwā Mu'āṣirah. Dikumpul dan disusun oleh Mahmūd, Șalāh al-Dīn. Al-Manșūrah: Dār al-Ghadd al-Jad̄̄d.

Al-Uthmān̄ì, Muḥammad Taqī . (t.t). "Aḥkām al-Tawarruq wa Taṭbīqātuh al-Mașrafiyah," Munzamah alMu'tamar al-Islām-' Majma ' al-Fiqh al-Islām- al-Duwal' (al-Dawrah al-Tāsi 'ah 'Asharah), Imārat al-Shāriqah Dawlat al-Imārāt al-'Arabiyyat al-Muttahadah).

Al-Zuhaylī, Wahbah. (2004). Al-Fiqh al-Islām wa Adillatuh. Damshiq: Dāral-Fikr, 5:3475. 
'Al̄̄ Maḥmūd, Mạ̣mūd Muḥammad. (2012). "Ikhtilāf Ārā’a al-Fuqahā' Hawla Taṭī̄ Muntajāt alTawarruq al-Munażam, wa Bay‘ al-'Īnah, wa al-Dayn fī al-Mașārif al-Islāmiyah," Majallat alIslām $F^{-} \bar{A}$ siya $\bar{a}$, Volume 9, No. 2.

Amiruddin Amri (Pengurus Pembangunan Perniagaan, Sedania As Salam Capital Sdn Bhd, Petaling Jaya, Malaysia), dalam temu bual dengan penyelidik, 11 Mac 2014.

Bouheraoua, Sa'id. "Tawarruq in the Banking System: A Critical Analytical Study of Juristic Views on the Topic," OIC Fiqh Academy (19 Session), Sharjah Emirate, United Arab Emirates). Diakses melalui laman sesawang ISRA, http://www.isra.my/media-centre/downloads/finish/20-oic-fiqhacademy-19th-session/86-tawarruq-in-the-banking-system-a-critical-analytical-study-of-juristicviews-on-the-topic-english/0.html. Tarikh akses: 11 Jun 2013.

Dusuki, Asyraf Wajdi. (2010) "Can Bursa Malaysia's Suq al-Sila' (Commodity Murabahah House) Resolve the Controversy over Tawarruq?" ISRA Research Paper, no. 10 (2010). Diakses melalui www.isra.my/media-centre/downloads/summary/29/186.html.Tarikh akses: 5 November 2011.

Ḥamād, Nazīh. (1993). Mu 'jam al-Muștalahāt al-Iqtiṣādiyah $f^{2}$ Lughah al-Fuqahā'. Herndon, Virginia: al-Ma'had al-'Ālamī lilfikr al-Islāmī, 108.

Ibn Juzayy. (t.t). Al-Qawānayn Al-Fiqhiyah. Beirut: Darul Qalam, 179.

Islamic Finance Knowledge Repository (I-FIKR). Diakses melalui http://ifikr.isra.my. Tarikh akses: 22 Januari 2013.

Kamis@Che Ali, Mohammad Nasir (Senior Manager, Cards and Unsecured Business, RHB Islamic Bank Berhad), dalam temubual dengan penyelidik, 5 Mac 2014.

Khnifer, Mohammed. (2013). "Istaghillū Ghiyāb "al-Mudaqqiq" al-Shar'iyy wa Fatawā Ijāzatihi min alFuqahā' Qabla 'Aqdayn Wasațā' Bunūk Gharbiyūn Yumārisūn al-Iḥtiyāl fi 'Uqūd Murabahah Qīmatihā Tirīliyūn Dūlār," al-Iqtiṣādiyah. Diakses melalui http://www.aleqt.com/2009/08/09/ article_260961.html. Tarikh akses: 19 Februari 2013.

Laldin, Mohamad Akram, Abdul Khir, Mohamed Fairooz dan Mohd Parid, Nusaibah. "Fatwas in Islamic Banking: A Comparative Study between Malaysia and Gulf Cooperation Council (GCC) Countries", ISRA Research Paper, No. 31 (2012), 18.

London Metal Exchange. Diakses melalui http://www.lme.com/. Tarikh akses: 17 November 2014.

Majma' al-Fiqhī al-Islāmī (1419H). Resolutions of the Islamic Fiqh Council - 15th Session 1419H: The Fifth Resolution on Tawarruq Sale. Diakses melalui laman sesawang Muslim World League, http://en.themwl.org/2012/05/23/resolutions-of-the-islamic-fiqh-council-15th-session-1419h. Tarikh akses: 10 Mei 2013.

Munazzamah al-'Arabiyah li'l-Tarbiyah. (1988). Al-Mu'jam al-'Arabi al-Asasi li'l-natiqin bi-al'Arabiyah wa-muta'allimi-ha al-munazzamah al-'Arabiyah li'l-Tarbiyah wa-al-Thaqafah wa-al'ulum. T.tp.: Larus, 1302.

Muslim World League Islamic Fiqh Council. (2003). Resolutions of Islamic Fiqh Council - $17^{\text {th }}$ Session, Muslim World League Islamic Fiqh Council, Makkah al-Mukarramah.

Qal'ah Jī, Muhammad Rawwas. (1996). Mu'jam Lughat al-Fuqaha' 'Arab-Inkl'z-Ifrans' Waḍa'ahu Muhammad Rawwas Qal 'ah $J^{-}$Wạ̣a 'a Musțalaḥātah al-Faransiyyah Quṭb Muștafā Sanū. Bayrut: Dār al-Nafā' is.

Qal'ah Jì, Muḥammad Rawwās (2002). Al-Mu 'āmalāt al-Māliyah al-Mu 'ạșirah fi Daw' al-Fiqh wa alShar'‘ah. Bayrūt: Dār al-Nafā' is.

Rayner, S.E. (1991). The Theory of Contract in Islamic Law: A Comparative Analysis with Particular Reference to the Modern Legislation in Kuwait, Bahrain and The United Arab Emirates. London: Graham \& Trotman Ltd, 133.

RHB Islamic Bank. Product Disclosure Sheet. Boleh didapati di laman sesawang RHB Islamic Bank Berhad. Diakses melalui http://www.rhb.com.my/islamic_banking/product-disclosuresheet/PDS_PF-i_Private.pdf. Tarikh akses: 16 April 2014.

RHB Islamic Bank Berhad. Diakses melalui http://www.rhb.com.my/business_banking/ islamic_banking/ enterprisebanking/commercial_main.html. Tarikh akses: 17 April 2014. 
Saiful Azhar Rosly. (2005). Critical Issues on Islamic Banking and Financial Markets: Islamic Economics, Banking and Finance, Investments, Takaful and Financial Planning. Kuala Lumpur: Dinamas Publishing.

Shubayr, Muḥammad 'Uthmān. "Al-Tawarruq al-Fiqhī wa Taṭbīqātuhu al-Mașrafiyah al-Mu'āṣirah Fi alFiqhi al-Islāmī ," Munzamah al-Mu'tamar al-Islām-, Majma' al-Fiqh' al-Islām ${ }^{-}$al-Duwal' ( alDawrah al-Tāsi 'ah 'Asharah), Imārat al-Shāriqah Dawlat al-Imārāt al-'Arabiyyat al-Muttahadah

Sulaiman, Syahnaz, Bursa Suq Al-Sila': Platform Pengurusan Kecairan Tunai, boleh didapati di laman sesawang Portal e-Muamalat. Diakses melalui http://e-muamalat.gov.my/artikel/bursa-suq-al-silaplatform-pengurusan-kecairan-tunai. Tarikh akses: 17 November 2014.

Wizārah al-Awqāf wa al-Syu'ūn al-Islāmiyyah. (t.t). Al-Mawsū'ah Al-Fiqhiyyah. Kuwait: Wizārah alAwqāf wa al-Syu'ūn al-Islāmiyyah, 14:147. 